\title{
Yield Variation of Rice Selections for Aerobic Planting in Water Scarce Situations
}

\author{
Rahmani, Ahamd Farid, Abdul Wasi*, Amiri and S. Hittalmani \\ University of Agricultural Sciences, Bangalore - 560 065, Karnataka, India \\ *Corresponding author
}

A B S T R A C T

\begin{tabular}{|l|l|l|}
\hline Keywords & $\begin{array}{l}\text { An investigation with fourteen genotypes grown under water saving aerobic condition } \\
\text { revealed significant difference for all the characters studied except for 1000-grain weight. }\end{array}$ \\
$\begin{array}{l}\text { Yield variation, } \\
\text { Rice selections, } \\
\text { Aerobic planting }\end{array}$ & $\begin{array}{l}\text { Number of tillers, and grain yield recorded high phenotypic and high genotypic co- } \\
\text { efficient of variability. All the characters studied exhibited high heritability and characters } \\
\text { like, number of tillers, grain yield and fodder yield recorded high genetic advance as } \\
\text { percent over mean. Estimates of correlation coefficient indicated that fodder yield and } \\
\text { harvest index manifested positive and significant correlation with grain yield. At } \\
\text { phenotypic level, fodder yield followed by harvest index and days to first flowering } \\
\text { showed positive direct effect on grain yield. Whereas negative direct effect on grain yield } \\
\text { was exhibited by plant height and plant height had positive indirect effect through days to } \\
\text { first flowering. }\end{array}$ \\
\hline $\begin{array}{l}\text { Accepted: } \\
\text { Available Online: }\end{array}$ 10 July 2018
\end{tabular}

\section{Introduction}

Rice is mostly grown under submerged soil condition and requires much water and is labour intensive compared to other crops. It is estimated that 5000 liters of water is needed to produce one kilo gram of rice. Water is most limited natural resource of late, due to failure of rains and over-exploitation of ground water. The declining availability of water threatens the traditional way of irrigated rice production. Farmers are seeking alternate methods of cultivation for growing rice to combat this water scares situation. Aerobic rice is one such method to overcome water shortage problem. University of Agricultural Sciences, Bangalore has made a pioneering effort to develop rice varieties for aerobic cultivation and also they have standardized the irrigation schedule and package of practices for maximization of yield (Shailaja Hittalmani, 2007).

To make aerobic rice successful, new varieties and management practices must be developed. Considerable work is in progress in identifying the suitable genotype of rice for unpuddled conditions. However, the performance of genotypes with respect to plant growth, yield and quality vary greatly under aerobic condition. Further, there is no systematic study and information available with respect to suitability of different rice genotypes under aerobic conditions. 
Therefore, there is a felt need to evaluate the rice genotypes that are suitable for aerobic conditions.

\section{Materials and Methods}

Fourteen elite rice genotypes, obtained from Marker Assisted Selection (MAS) lab, Department of Genetics and Plant Breeding, UAS, GKVK, The MAS genotypes were developed by introgression of the traits of root morphological parameters, water use efficiency and high yielding characters. The donor lines used to develop the genotypes were, IR64, Azucena, Moroberekan and Doddi gentoypes. During Kharif- 2007, fourteen elite rice genotypes were sown in the field. The experiment was laid out in a randomized block design (RCBD). Each genotype was sown in $5 \times 3$ square meter plots with spacing of $30 \mathrm{~cm}$ between the plant and $25 \mathrm{~cm}$ between rows. Aerobic condition was maintained by giving irrigation once in seven days when there was no rainfall. The crop was mostly maintained by rainfall. For Determination of $\Delta^{13} \mathrm{c}$ the plant material was dried at $80^{\circ} \mathrm{C}$ after which the samples were powdered in a ball mill. The powdered sample was stored in labeled Eppendorf tubes until analysis. The $\Delta^{13} \mathrm{c}$ of the leaf samples were determined using the Isotope Ratio Mass Spectrometer (IRMS) at the National Facility for stable isotope studies in biological sciences in the Department of Crop Physiology, UAS, Bangalore.

\section{Results and Discussion}

Analysis of variance for yield and yield attributes in rice genotypes presented in Table 1 indicated significant difference for all the characters studied except for 1000-grain weight. Mean, range, phenotypic and genotypic variance, phenotypic and genotypic co-efficient of variation, heritability and genetic advance in respect to yield and yield attributing characters is presented in Table 2.
Days to first flowering, Days to $50 \%$ flowering, Days to maturity, Panicle length and 1000-grain weight exhibited low PCV and GCV values. Harvest index exhibited low GCV but moderate PCV Number of tillers, and grain yield recorded high PCV and GCV fodder yield also recorded high GCV. All the characters studied exhibited high heritability and characters like, number of tillers, grain yield and fodder yield recorded high genetic advance as percent over mean.

Estimates of correlation coefficient indicated that fodder yield $\left(\mathrm{r}=0.6219^{*}\right)$ and harvest index $\left(r=0.5841^{*}\right)$ manifested positive and significant correlation with grain yield. Significant influence of total dry matter on grain yield was also reported by Sundaram et al., 1988; Yadav et al., 1988 and Nanaja reddy et al., 1996). The harvest index is usefull measure of yield and is positively correlated with yield (Singh and Staskoppf, 1971). Strong positive association between grain yield and harvest index was reported by many workers Nakano, 1989; Deosarkar and Narkar, 1995; Yolanda and Das, 1995 and Chauhan, 1996).

At phenotypic level, fodder yield (0.8419) followed by harvest index (0.7947) and days to first flowering (0.0762) showed positive direct effect on grain yield. Where as negative direct effect on grain yield was exhibited by plant height (-0.0433) and plant height had positive indirect (0.0330) effect through days to first flowering. Fodder yield recorded high magnitude of positive direct effect on grain yield followed by harvest index was reported by Surek et al., (1998) and Meenakshi et al., (1999). Mokate et al., (1998) reported that straw yield was the important yield contributing character. Chen et al., 1986; Balaln et al., 1999; Venkataravana 1991 and Bagali et al., 1999 reported strong direct positive effect of harvest index on grain yield at phenotypic level (Table 3 and 4). 
Table.1 Analysis of variance for yield and yield attributes in rice genotypes

\begin{tabular}{|c|c|c|c|c|c|c|c|c|c|c|c|}
\hline Source & d.f. & $\begin{array}{l}\text { Plant } \\
\text { height }\end{array}$ & $\begin{array}{c}\text { Days to } \\
\text { first } \\
\text { flowering }\end{array}$ & $\begin{array}{c}\text { Days to } 50 \\
\% \\
\text { flowering }\end{array}$ & $\begin{array}{l}\text { Days to } \\
\text { maturity }\end{array}$ & $\begin{array}{l}\text { Number } \\
\text { of tillers }\end{array}$ & $\begin{array}{l}\text { Panicle } \\
\text { length }\end{array}$ & $\begin{array}{c}1000 \\
\text { grain } \\
\text { weight }\end{array}$ & $\begin{array}{c}\text { Grain yield } \\
\text { (kg/ha) }\end{array}$ & $\begin{array}{l}\text { Fodder yield } \\
\text { (kg/ha) }\end{array}$ & $\begin{array}{c}\text { Harvest } \\
\text { index } \\
(\%)\end{array}$ \\
\hline Replication & 2 & 812.08 & 13.31 & 19.60 & 14.38 & 10.31 & 0.15 & 0.08 & 48308.92 & 499626.61 & 21.31 \\
\hline Genotypes & 13 & $290.92 * *$ & $183.92 * *$ & $106.03 * *$ & $121.68 * *$ & $192.84 * *$ & $2.61 * *$ & 1.93 & $1884458.37 * *$ & $2112567.41 * *$ & $54.23 * *$ \\
\hline Error & 26 & 54.60 & 6.75 & 3.49 & 8.12 & 11.31 & 0.28 & 0.05 & 105695.11 & 212855.85 & 11.94 \\
\hline Total & 41 & 166.48 & 63.24 & 36.79 & 44.43 & 68.82 & 1.01 & 0.65 & 666893.89 & 829192.24 & 25.81 \\
\hline
\end{tabular}

Table.2 Mean, range, phenotypic and genotypic variance, phenotypic and genotypic co-efficient of variation, heritability and genetic advance in respect to yield and yield attributing characters in rice

\begin{tabular}{|c|c|c|c|c|c|c|c|c|c|}
\hline Characters & Mean \pm SE & Range & $\mathbf{V p}$ & Vg & PCV & GCV & $\begin{array}{c}\text { Heritability } \\
(\%)\end{array}$ & GA & GA $(\%)$ \\
\hline Plant height & $75.89 \pm 1.99$ & $64.13-106.02$ & 345.52 & 78.77 & 11.70 & 15.22 & 59.06 & 14.05 & 18.51 \\
\hline Days to first flowering & $90.93 \pm 1.23$ & $73-102$ & 190.67 & 59.06 & 8.44 & 8.91 & 89.75 & 15.00 & 16.48 \\
\hline Days to $50 \%$ flowering & $104.57 \pm 0.94$ & $92-114$ & 109.52 & 34.18 & 5.59 & 5.87 & 90.73 & 11.47 & 10.97 \\
\hline Days to maturity & $132.29 \pm 1.03$ & $122-147$ & 129.80 & 37.85 & 4.66 & 5.13 & 82.33 & 11.50 & 8.70 \\
\hline Number of tillers & $35.57 \pm 1.29$ & $14-48$ & 204.15 & 60.51 & 21.78 & 23.64 & 84.89 & 14.76 & 41.33 \\
\hline Panicle length & $22.01 \pm 0.16$ & $20.21-23.64$ & 2.89 & 0.78 & 4.01 & 4.67 & 73.76 & 1.56 & 7.09 \\
\hline 1000 grain weight & $23.39 \pm 0.12$ & $21.80-24.63$ & 1.98 & 0.63 & 3.39 & 3.52 & 93.03 & 1.58 & 6.74 \\
\hline Grain yield (Kg/ha) & $3494.86 \pm 126.02$ & $2216-5280$ & 1990153.48 & 592921.09 & 22.03 & 23.92 & 84.87 & 2.19 & 41.81 \\
\hline Fodder yield (Kg/ha) & $4552.21 \pm 140.51$ & $2858-6056$ & 2325423.26 & 633237.19 & 17.48 & 20.21 & 74.84 & 2.13 & 31.15 \\
\hline Harvest index (\%) & $43.36 \pm 0.78$ & $36.55-49.00$ & 66.17 & 14.10 & 11.77 & 8.66 & 54.13 & 5.69 & 13.12 \\
\hline
\end{tabular}


Table.3 Phenotypic correlation co-efficient value of grain yield and yield components in rice genotypes

\begin{tabular}{|c|c|c|c|c|c|c|c|c|c|c|c|}
\hline Characters & PH & DFF & DF50\% & DM & NT & PL & $\Delta^{13} \mathrm{C}$ & TW & FY & HI & GY \\
\hline PH & 1 & 0.4349 & 0.1367 & $0.5440^{*}$ & $-0.8528 * *$ & 0.1320 & 0.0307 & -0.0144 & -0.4197 & -0.1093 & -0.4496 \\
\hline DFF & & 1 & $0.6899 * *$ & $0.7123^{* *}$ & -0.4281 & -0.3084 & 0.1250 & -0.3850 & -0.3810 & -0.0067 & -0.2598 \\
\hline DF50\% & & & 1 & $0.8148 * *$ & -0.2073 & $-0.5695^{*}$ & $0.6213^{*}$ & -0.3406 & -0.3098 & -0.0392 & -0.2400 \\
\hline DM & & & & 1 & $-0.6447^{*}$ & -0.4003 & 0.3625 & -0.1737 & -0.4144 & -0.0358 & -0.3278 \\
\hline NT & & & & & 1 & -0.0772 & -0.0120 & -0.2083 & 0.3829 & -0.0290 & 0.3097 \\
\hline PL & & & & & & 1 & -0.3654 & 0.0057 & 0.3533 & -0.1904 & 0.1440 \\
\hline$\Delta^{13} \mathrm{C}$ & & & & & & & 1 & -0.2984 & 0.0801 & -0.1488 & -0.0372 \\
\hline TW & & & & & & & & 1 & 0.1722 & 0.4433 & 0.4118 \\
\hline FY & & & & & & & & & 1 & -0.2596 & $0.6219 *$ \\
\hline HI & & & & & & & & & & 1 & $0.5841 *$ \\
\hline GY & & & & & & & & & & & 1 \\
\hline
\end{tabular}

\begin{tabular}{|c|c|c|c|c|c|c|c|}
\hline PH & Plant height $(\mathrm{cm})$ & DFF & Days to first flowering & DF50\% & Days to $50 \%$ flowering & DM & Days to maturity \\
\hline NT & Number of tillers & PL & Panicle length (cm) & $\Delta^{13} \mathbf{C}$ & $\Delta^{13} \mathrm{C}$ values (Water use efficiency) & TW & Test weight $(\mathrm{g})$ \\
\hline FY & $\begin{array}{l}\text { Fodder yield }(\mathrm{kg} / \mathrm{ha}) \\
\text { ignificance at } \mathrm{n}<0\end{array}$ & HI & $\begin{array}{l}\text { Harvest index }(\%) \\
* * \text { Significance at } \mathfrak{p}\end{array}$ & GY & Grain yield (kg/ha) & & \\
\hline
\end{tabular}

Table.4 Path co-efficient analysis showing the direct and indirect effects of different characters on grain yield in rice at phenotypic level

\begin{tabular}{|l|l|c|c|c|c|}
\hline \multicolumn{1}{|c|}{ Characters } & $\begin{array}{l}\text { Plant } \\
\text { height }\end{array}$ & $\begin{array}{l}\text { Days to first } \\
\text { flowering }\end{array}$ & $\begin{array}{l}\text { Fodder } \\
\text { yield }\end{array}$ & $\begin{array}{l}\text { Harvest } \\
\text { index }\end{array}$ & $\begin{array}{l}\text { Correlation with } \\
\text { grain yield (kg/ha) }\end{array}$ \\
\hline Plant height & -0.0433 & 0.0330 & -0.3532 & -0.0871 & $\mathbf{- 0 . 4 4 9 6}$ \\
\hline Days to first flowering & -0.0188 & 0.0762 & -0.3131 & -0.0037 & $\mathbf{- 0 . 2 5 9 8}$ \\
\hline Fodder yield & 0.0182 & -0.0283 & 0.8419 & -0.2061 & $\mathbf{0 . 6 2 1 9 *}$ \\
\hline Harvest index & $\mathbf{0 . 0 0 4 8}$ & $\mathbf{- 0 . 0 0 0 4}$ & $\mathbf{- 0 . 2 1 8 3}$ & $\mathbf{0 . 7 9 4 7}$ & $\mathbf{0 . 5 8 4 1}$ \\
\hline
\end{tabular}




\section{References}

Atlin, G.N., H.R. Lafi tte, D. Tao, M. Laza, M. Amante, and B. Courtois. 2006. Developing rice cultivars for high-fertility upland systems in the Asian tropics. Field Crops Res. 97:43-52.

Bouman, B.A.M., R.M. Lampayan, and T.P. Tuong. 2007. Water management in irrigated rice: Coping with water scarcity. International Rice Research Institute, Los Baños, Philippines.

Bouman, B.A.M. 2007. The aerobic rice reality. Rice Today 6:38.

Bouman, B.A.M., S. Peng, A.R. Castañeda, and R.M. Visperas. 2005. Yield and water use of tropical aerobic rice systems. Agric. Water Manage. 74:87-105.

Bagali, G. P. Hittalmamani, S. and Shashidhar, H. E., 1999, Character association in path coefficient analysis in indica $\times$ japonica doubled haploid population of rice. Oryza 36(1): 10-12.

Balan, A., Muthiah, A. R. and Ramachandra Boopathi, S. N. M., 1999, Genetic variability, correlation and path coefficient analysis in uopland early rice genotypes. Madras Agric. J., 86(1-3): 7-9.

Chauhan, J. S., 1996, Genotypic and phenotypic correlations between grain yield and other associated characters in very early duration elite breeding cultures of rice. Oryza, 33: 26-30.

Deosarkar, D. B. and Nerkar, Y. S., 1995, Correlation and path coefficient analysis between yield, components and iron chlorosis mean index in rice. PKV Res. J., Marathwad Agricultural University, Parbhani, Maharastra, 19(2):176-177.

Hittalmani S 2007. Aerobic rice cultivation brochure, MAS LAB, Univ.Agric. Sci., GKVK.Bangalore, India.

Meenakshi, T., Rathinam, D. A. A. and
Backiyarani, S., 1999, Correlation and path analysis of yield and physiological characters in rainfed rice. Oryza, 36(2): 154156.

Mokate, A. S., Bendale, V. W. And Birari, S. P., 1998, Variability, heritability, correlation and path analysis studies in rice (Oryza sativa L.). Crop Res., 15 (2 and 3): 221-226.

Nakano, J. I., 1989, Analysis of yield differences among rice varieties of different seed size with special attention to grain process. Memories of the college of Agriculture, Kyoto University, Japan, No. 135, pp 18.

Nanjareddy, Y. A., Prasad, T. G. and Udayakumar, M., 1996, Association of assimilation rate with growth and yield in rice. Oryza, 33: 79-83.

Shailaja Hittalmani 2007, MAS-946-1, a new aerobic rice variety for dry soils of Karnantaka. In: Extension bulletin. Pp. 4.

Singh, T. D. and Staskoppf, N. C., 1971, Harvest index in cereals. Agron. J. 63:224-225.

Sundaram, T., Wilfred Manuel, W. and Palaniswamy, S., 1988, Genetic variability and correlation coefficient in early rice. Indian J. Agric. Sci., 8: 629-330.

Surek, H., Korkut, Z. K. And Belgain, O., 1998, Correlation and path analysis for yield and yield components in a eight parent half diallele set of crosses. Oryza, 36(1): 15-18.

Venkataravana, P., 1991, Studies on genetic variability, charcter association and path coefficient analysis in $\mathrm{F}_{2}$ segregants of rice (Oryza sativa L.) under irrigated aerobic conditions. M.Sc. (Agri) Thesis, Univ. Agri. Sci., Bangalore.

Yadav, M. S., Bana, D. P. S. and Singh, M., 1988, Vegetative characters limiting yield in rice genotypes. Ind, J. Bot., 11(1): 74-81.

Yolanda, J. L. and Das, L. D. V., 1995, Correlation and path analysis in rice (Oryza sativa L.). Madras Agric. J., 82: 576-578.

\section{How to cite this article:}

Rahmani, Ahamd Farid, Abdul Wasi, Amiri and Hittalmani, S. 2018. Yield Variation of Rice Selections for Aerobic Planting in Water Scarce Situations. Int.J.Curr.Microbiol.App.Sci. 7(07): 1533-1537. doi: https://doi.org/10.20546/ijcmas.2018.707.180 